\title{
Thermal Analysis of the Essential Oil of Aniba rosaeodora Ducke by TGA and DSC
}

\author{
Análise Térmica do Óleo Essencial de Aniba rosaeodora Ducke por TG e DSC \\ Análisis térmico del aceite esencial de Aniba rosaeodora Ducke por TG y DSC
}

Received: 01/24/2022 | Reviewed: 01/29/2022 | Accept: 02/05/2022 | Published: 02/10/2022

\author{
Rogerio de Mesquita Teles \\ ORCID: https://orcid.org/0000-0001-9789-1847 \\ Federal Institute of Education Science and Technology of Maranhao, Brazil \\ E-mail: rogerioteles@ifma.edu.br \\ Victor Elias Mouchrek Filho \\ ORCID: https://orcid.org/0000-0003-2855-7292 \\ Federal University of Maranhão, Brazil \\ E-mail: victor.mouchrek@ufma.br
}

\begin{abstract}
Thermal analysis comprises a group of techniques to measure a physical property of a sample subjected to controlled temperature programming, including thermogravimetry (TGA), derivative thermogravimetry (DTG) and differential scanning calorimetry (DSC). The species Aniba duckei Kostermans, synonymous with Aniba rosaeodora Ducke, occurs in the Amazon and is also known as rosewood. Essential oils are complex oily aromatic liquids obtained by extraction from highly volatile aromatic plant materials as secondary metabolites. This research aimed to chemically and thermally characterize the essential oil of Aniba duckei. Gas chromatography was used for the quantification, by the external standard method, of the main component. The thermal study of the oil and the linalool standard was carried out using DSC and TG-DTG. The essential oil yield was $1.93 \%$ and the analysis by GC-MS confirmed the majority presence of linalool, with a concentration of $89.34 \%$ in the oil. The technical analysis revealed some similarity between the curves of pure linalool and essential oil, which is attributed to the high content of linalool in the oil. The differences between the boiling points and enthalpies of the linalool and oil pattern are justified by the presence of minor components, their concentrations in the oil and because they are substances of different polarities, molecular masses and intermolecular forces. The techniques proved to be efficient to characterize the oil. The results of the thermal analysis of the essential oil of the Aniba rosaeodora plant species are unprecedented, enabling the determination of linalool in by DSC.
\end{abstract}

Keywords: Essential oil; Aniba rosaeodora Ducke; Aniba duckei Kostermans; Linalool; Thermal analysis.

\section{Resumo}

A análise térmica compreende um conjunto de técnicas para medir uma propriedade física de amostra submetida a programação de temperatura controlada, incluindo termogravimetria (TGA), termogravimetria derivada (DTG) e calorimetria exploratória diferencial (DSC). A espécie Aniba duckei Kostermans, sinonímia de Aniba rosaeodora Ducke, ocorre na Amazônia e é também conhecida como pau-rosa. Os óleos essenciais são líquidos aromáticos oleosos complexos obtidos por extração de materiais vegetais aromáticos altamente voláteis, como metabólitos secundários. Esta pesquisa teve como objetivo caracterizar química e termicamente o óleo essencial de Aniba duckei. A cromatografia gasosa foi utilizada para identificação e quantificação do componente principal, pelo método de padrão externo. O estudo térmico do óleo e do padrão linalol foi realizado utilizando DSC e TG-DTG. O rendimento de óleo essencial foi de 1,93\% e a análise por GC-MS confirmou a presença majoritária de linalol, com concentração de $89,34 \%$ no óleo. A análise técnica revelou semelhança entre as curvas de linalol puro e as do óleo essencial, o que é atribuído ao alto teor de linalol no óleo. As diferenças entre os pontos de ebulição e entalpias do padrão do linalol e do óleo são justificadas pela presença de componentes minoritários, suas concentrações no óleo e por serem substâncias de diferentes polaridades, massas moleculares e forças intermoleculares. As técnicas se mostraram eficientes para caracterizar o óleo. Os resultados da análise térmica do óleo essencial da espécie vegetal Aniba rosaeodora são inéditos, possibilitando a determinação do linalol por DSC.

Palavras-chave: Óleo essencial; Aniba rosaeodora Ducke; Aniba duckei Kostermans; Linalol; Análise térmica.

\section{Resumen}

El análisis térmico comprende un grupo de técnicas para medir una propiedad física de una muestra sujeta a programación de temperatura controlada, que incluye termogravimetría (TGA), termogravimetría derivada (DTG) y calorimetría diferencial de barrido (DSC). La especie Aniba duckei Kostermans, sinónimo de Aniba rosaeodora Ducke, se encuentra en el Amazonas y también se conoce como palo de rosa. Los aceites esenciales son líquidos aromáticos aceitosos complejos obtenidos por extracción de materiales vegetales aromáticos altamente volátiles como metabolitos secundarios. Esta investigación tuvo como objetivo caracterizar química y térmicamente el aceite esencial 
de Aniba duckei. Se utilizó cromatografía de gases para la cuantificación, por el método del patrón externo, del componente principal. El estudio térmico del aceite y del estándar de linalol se realizó mediante DSC y TG-DTG. El rendimiento de aceite esencial fue de 1,93\% y el análisis por GC-MS confirmó la presencia mayoritaria de linalol, con una concentración de 89,34\% en el aceite. El análisis técnico reveló cierta similitud entre las curvas del linalol puro y el aceite esencial, lo que se atribuye al alto contenido de linalol en el aceite. Las diferencias entre los puntos de ebullición y las entalpías del patrón del linalol y del aceite se justifican por la presencia de componentes minoritarios, sus concentraciones en el aceite y por tratarse de sustancias de diferente polaridad, masa molecular y fuerzas intermoleculares. Las técnicas demostraron ser eficientes para caracterizar el aceite. Los resultados del análisis térmico del aceite esencial de la especie vegetal Aniba rosaeodora no tienen precedentes, permitiendo la determinación de linalool por DSC.

Palabras clave: Aceite esencial; Aniba rosaeodora Ducke; Aniba duckei Kostermans; Linalol; Análisis térmico.

\section{Introduction}

\section{Essencial oils}

Brazilian biodiversity is one of the richest on the planet, with a high rate of biological endemism, dispersed in unique biomes (Maia et al., 2009; Barata, 2012; Joly et al., 2011). Natural products are produced by plants, as the specimens produce their own food and also have the ability to deal with adverse situations. In an irregular environment, they produce certain chemicals called secondary metabolites, which are used as an attack and defense mechanism (Nazir et al., 2021).

Among these secondary metabolites are essential oils, which are volatile, lipophilic, odorous and liquid products extracted from different parts of aromatic plants, which have different and complex chemical composition and guarantee adaptive advantages to the plants in the environment in which they are inserted (Oussalah et al., 2007; Hasani et al., 2018; Tuğçe et al., 2021). Essential oils are mainly composed of monoterpenes, sesquiterpenes and phenylpropanoids, metabolites that confer their organoleptic characteristics. Essential oils from various plant species are used in perfumery, cosmetics, food and as adjuvants in medicines, being considered important in commercial and monetary aspects (Bizzo et al., 2009; Kreutz et al., 2021).

\section{The Vegetal Species Aniba rosaeodora Ducke}

The botanical species Aniba duckei Kostermans, synonymous with Aniba rosaeodora Ducke (Maia, 2000; Teles et al., 2018), of the Lauraceae family, commonly known as rosewood, was discovered in Brazil in Juriti Velho, in the state of Pará in 1925 (Correa et al., 1975; Siani et al., 2000). Its tree can reach up to 30 meters in height and its trunk 2 meters in diameter. The flowers are ferruginous and the fruit is a drupe, 2 to $3 \mathrm{~cm}$ long (Sampaio et al., 2005). The extraction of native essences such as Aniba rosaeodora, began to consolidate during the Second World War (Vivan et al., 2011).

Aniba rosaeodora essential oil is characterized by its strong odor, colorlessness and density lower than that of water, solubility in usual organic solvents and $70^{\circ} \mathrm{GL}$ alcohol, being linalool (3,7-dimethyl-oct-1,6-dien -3-ol) the major constituent. Linalol has wide application in several areas, being used as a starting point in important syntheses such as that of linanyl acetate and tested as an acaricide, bactericide and fungicide, sedative and anticonvulsant. A recent application for the oil is in aromatherapy. It is a product in great demand internationally for its use as a fixative in perfumes, for example the famous Chanel number 5 (Chaar, 2000; Sudam, 1971; Teles, Mouchrek Filho et al., 2017).

\section{Thermal analysis}

Thermal Analysis is a group of techniques, in which a physical property of a substance and/or its reaction products is measured, while the sample is subjected to controlled temperature programming (Mackenzie, 1993; Ionashiro \& Giolito, 2004). 


\section{Thermogravimetry (TGA) and Derived Thermogravimetry (DTG)}

Thermogravimetry is a technique in which the mass variation (loss or gain) that occurs in the sample is monitored as a function of time (constant temperature) or as a function of temperature. The measurement is performed using an equipment called a thermobalance, which consists of a combination of an electronic microbalance coupled to an oven and a linear temperature programmer, allowing the continuous weighing of a sample as a function of temperature, as the sample is heated or cold (Santos et al., 2004; Aslan et al., 2018; Mallick et al., 2018).

Derived thermogravimetry (DTG) is the first derivative of the thermogravimetric curve, that is, the derivative of mass variation in relation to time or temperature. The DTG curve presents the information in a clearer way, with the area being directly proportional to the mass variation, leading to the prompt determination of the peak temperature and indicating the initial and final temperatures of the process (Gonçalves, Teixeira \& Teixeira, 2003).

\section{Differential Scanning Calorimetry (DSC)}

Differential Scanning Calorimetry (DSC) is the technique in which the difference in energy released or absorbed by the sample is measured, in relation to a thermally inert reference material, as a function of temperature, while the sample and the reference are subjected to a temperature programming (Bernal et al., 2002).

When a material undergoes a change of physical state or chemical reaction, heat is released or absorbed. During the thermal event, the DSC measures change in the thermal energy of the sample. In general, phase transition, dehydration, reduction and some decomposition reactions produce endothermic effects, while crystallization, oxidation and some decomposition reactions produce exothermic effects (Dantas, 2006).

\section{Thermal Analysis of Essential Oils}

There are vast and diverse applications of thermal analysis in industrial activities, such as chemical, pharmaceutical, cosmetics, food and petrochemicals, among others. There is also the literature on thermal analysis of essential oils, for characterization, evaluation of their thermal behavior, stability and investigation of possible adulteration (Hazra et al., 2002; Hazra et al., 2004; Monteiro et al., 2011; Cremasco et al., 2011; Siqueira et al., 2016).

However, there is no research in the literature on thermal analysis of essential oil of the plant species aniba rosaeodora Ducke nor of species in its family - Lauraceae. Thus, the present work reports the research in which the chemical characterization and thermal analysis of the essential oil of the plant species Aniba rosaeodora Ducke and its major component - linalool - was carried out by Thermogravimetric Analysis (TGA) and by Differential Scanning Calorimetry (DSC).

\section{Methodology}

This research was developed in the Laboratory of Fuels and Materials (LACOM) located at Federal University of Paraiba (UFPB) in partnership with Laboratory of Researches and Tests of Fuels (LAPEC) at Federal University of Amazonas (UFAM) and Sao Carlos Institute of Chemistry, from University of Sao Paulo (USP).

\section{Plant sample collection, extraction and chromatographic analysis of essential oil}

Samples of leaves and twigs were collected from three Aniba rosaeodora Ducke trees cultivated in Ducke Forest

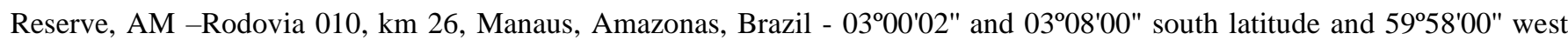
longitude).

The essential oil was extracted from 30 grams of the sample with $300 \mathrm{~mL}$ of distilled water, by hydrodistillation, in a Clevenger system, and the oil was dried by percolation in anhydrous $\mathrm{Na}_{2} \mathrm{SO}_{4}$. The yield was calculated in the mass/mass ratio. 
GC-MS essential oil analysis was performed on a Varian chromatograph, model 3900, using helium as carrier gas with flow in the column of $1 \mathrm{~mL} \mathrm{~min}^{-1}$; Injector temperature: $270^{\circ} \mathrm{C}$, split 1:50; capillary column $(30 \mathrm{~m} \times 25 \mathrm{~mm})$ by stationary phase VF-1ms $(100 \%$ methylsiloxane $0.25 \mu \mathrm{m})$ and oven temperature programmed to $60^{\circ} \mathrm{C}$ and then increased to $220^{\circ} \mathrm{C}$ at a rate of $4^{\circ} \mathrm{C} \mathrm{min}{ }^{-1}$ and then increased again to $260^{\circ} \mathrm{C}$, this time at a rate of $1^{\circ} \mathrm{C} \mathrm{min}^{-1}$, with total running time of 100 minutes. For mass spectrometer, the manifold, ion trap and transfer line temperatures were set to 50,190 and $200^{\circ} \mathrm{C}$, respectively. 1.0 $\mu \mathrm{L}$ (automatic injector CP-8410) aliquots of the samples diluted were injected in proportion of $20 \mu \mathrm{L}$ for $1.5 \mathrm{~mL}$ of hexane. Linalool was quantified by the external standard method, considering its high concentration in the samples.

For identification of the compounds the spectral databases of the spectral libraries NIST105, NIST21, WILEY139 and AMSDIS (Automated Mass Spectral De-convolution Mass \& Identification System) software were used, as well as references (Teles et al., 2018; Namara et al., 2007; Adams, 2001). For linalool, confirmation was also by addition of standard.

\section{Thermal analysis}

The calorimetric curves were obtained in a Thermal Analyzer, brand TA INSTRUMENTS, model SDT 2920 through the non-isothermal method of analysis, at a heating ratio of $10{ }^{\circ} \mathrm{C} \mathrm{min}-1$ and temperature range of $25-350{ }^{\circ} \mathrm{C}$, in order to verify the thermal decomposition profile. The DSC (Differential Scanning Calorimetry) curves of the essential oil of Aniba rosaeodora Ducke and of the linalool standard, stored in closed aluminum (Al) sample holders, with and without holes, in atmospheres of air or nitrogen gas $\left(\mathrm{N}_{2}\right)$, were obtained with a heating ratio of $10^{\circ} \mathrm{C} \mathrm{min}^{-1}$.

\section{Results}

From the essential oil chromatogram, the substances listed on Table 1 were identified, which include: the peak number in the order of elution, the retention time (tRET) of each substance in the column (in minutes), the name of the substance identified, the percentage of normalized area $(\% \mathrm{~A})$ which indicates the relative distribution of the compounds in the sample.

Table 1. Compounds identified in the essential oil of Aniba roseadora Ducke.

\begin{tabular}{c|c|c|c}
\hline Peak & tRET & Compound Name & \%A \\
\hline 1 & 15,61 & Limonene & 0,52 \\
2 & 15,71 & 1,8 -Cineol & 1,07 \\
3 & 17,43 & cis-linalool oxide & 1,94 \\
4 & 18,06 & trans-linalool oxide & 1,86 \\
\cline { 2 - 3 } 5 & 18,60 & Linalool & 89,34 \\
6 & 21,88 & $\alpha$-Terpineol & 3,06 \\
7 & 28,26 & $\alpha$-copaene & 0,89 \\
\cline { 3 - 4 } 8 & 31,74 & $\alpha$-Patchulene & 0,77 \\
9 & 32,02 & Cariophyllene & 0,55 \\
\cline { 2 - 3 } & \multicolumn{3}{|c}{} \\
\hline
\end{tabular}

Source: Authors.

\section{Thermal analysis}

Fig. 1 shows the results of the DSC analysis for $6.50 \mathrm{mg}$ of linalool standard sample (Figure 1A) and for $10.30 \mathrm{mg}$ of Aniba rosaeodora Ducke essential oil (Figure 1B), both in an Al pan without a hole with air atmosphere.

The DSC curve for the linalool shows a single endothermic peak, with a peak temperature of $204.11^{\circ} \mathrm{C}$ and an enthalpy of $213.4 \mathrm{~J} \mathrm{~g}^{-1}$. For the oil, there are two endothermic transitions, the first with a peak temperature of $107.32{ }^{\circ} \mathrm{C}$ and an enthalpy of $339.4 \mathrm{~J} \mathrm{~g}^{-1}$, and the second with peak temperature of $213.90{ }^{\circ} \mathrm{C}$ and enthalpy of $60.19 \mathrm{~J} \mathrm{~g}^{-1}$. 
Figure 1. DSC curves, aluminum pan without a hole, with a heating rate of $10{ }^{\circ} \mathrm{C} \mathrm{min}^{-1}$, in air atmosphere for: A) linalool standard; and B) essential oil of Aniba rosaeodora Ducke.
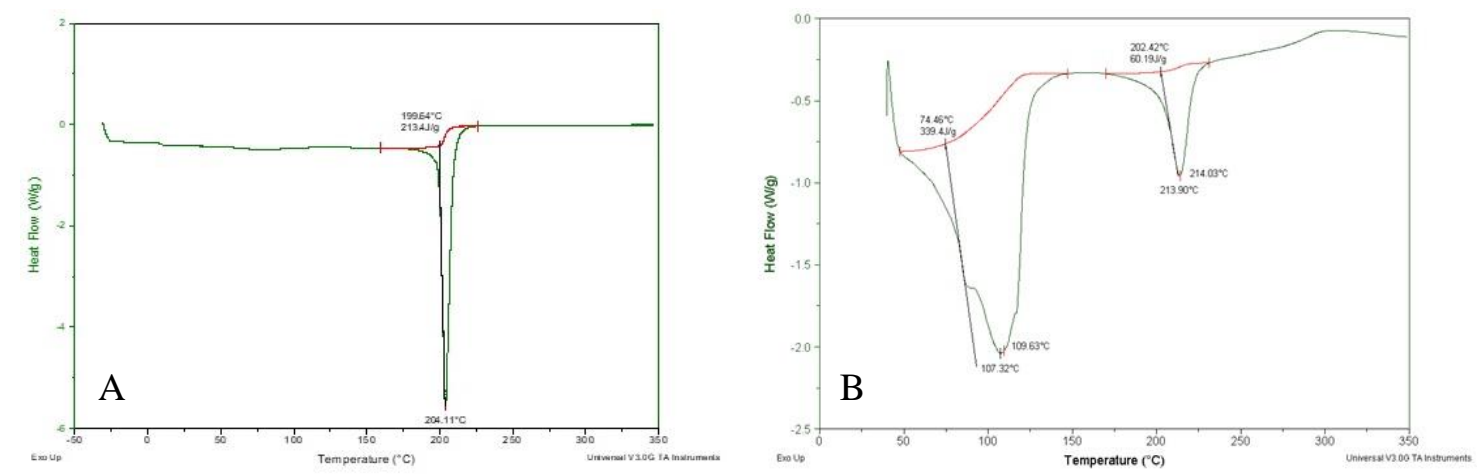

Source: Authors.

In nitrogen atmosphere, the DSC curve for $5.55 \mathrm{mg}$ of the standard of linalool and the sample of $10.00 \mathrm{mg}$ of essential oil of Aniba rosaeodora resulted in grafics showed in Fig. 2, A e B, respectively.

For the linalool standard, the DSC curve shows a single peak with a temperature of $206.24{ }^{\circ} \mathrm{C}$ and an enthalpy of 253.6 $\mathrm{J} \mathrm{g}^{-1}$. The sample of the essential oil of Aniba rosaeodora Ducke showed two endothermic transitions, the first with peak temperature of $106.12{ }^{\circ} \mathrm{C}$ and enthalpy of $360.5 \mathrm{~J} \mathrm{~g}^{-1}$, and the second with peak temperature of $209.90{ }^{\circ} \mathrm{C}$ and enthalpy of $62.88 \mathrm{~J} \mathrm{~g}^{-1}$.

Figure 2. DSC curves, aluminum pan without a hole, with a heating rate of $10{ }^{\circ} \mathrm{C} \mathrm{min}^{-1}$, in nitrogen atmosphere for: A) linalool standard; and B) essential oil of Aniba rosaeodora Ducke.
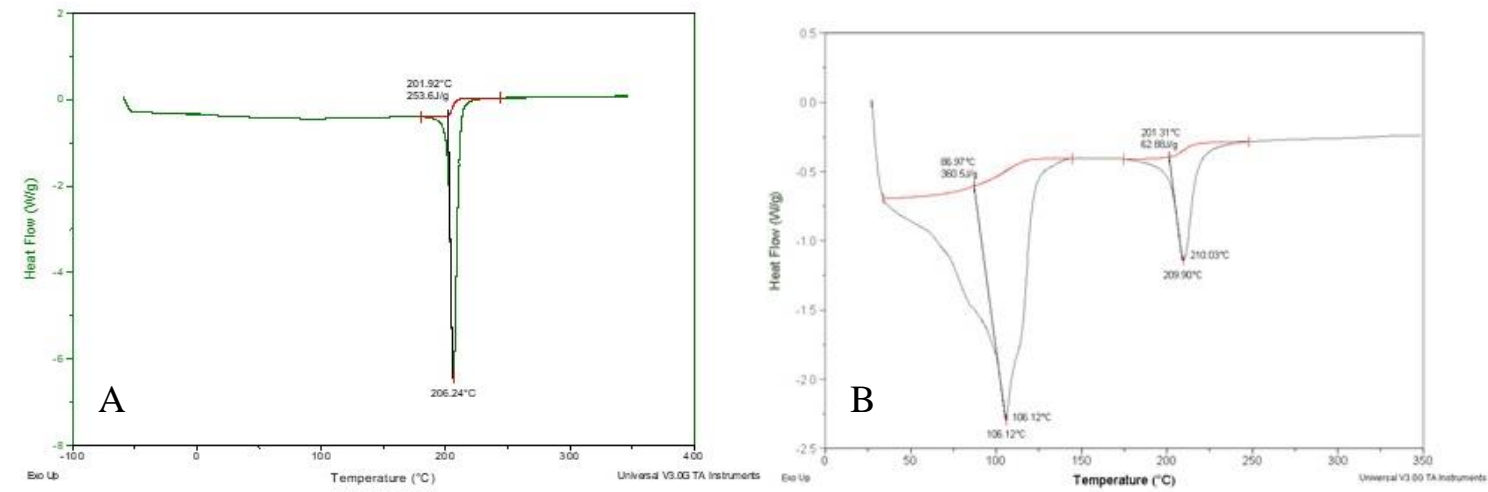

Source: Authors. 
Figure 3. TG-DTG curves, aluminum pan without a hole, with a heating rate of $10{ }^{\circ} \mathrm{C} \mathrm{min}^{-1}$, in air atmosphere for: A) linalool standard; and B) essential oil of Aniba rosaeodora Ducke.
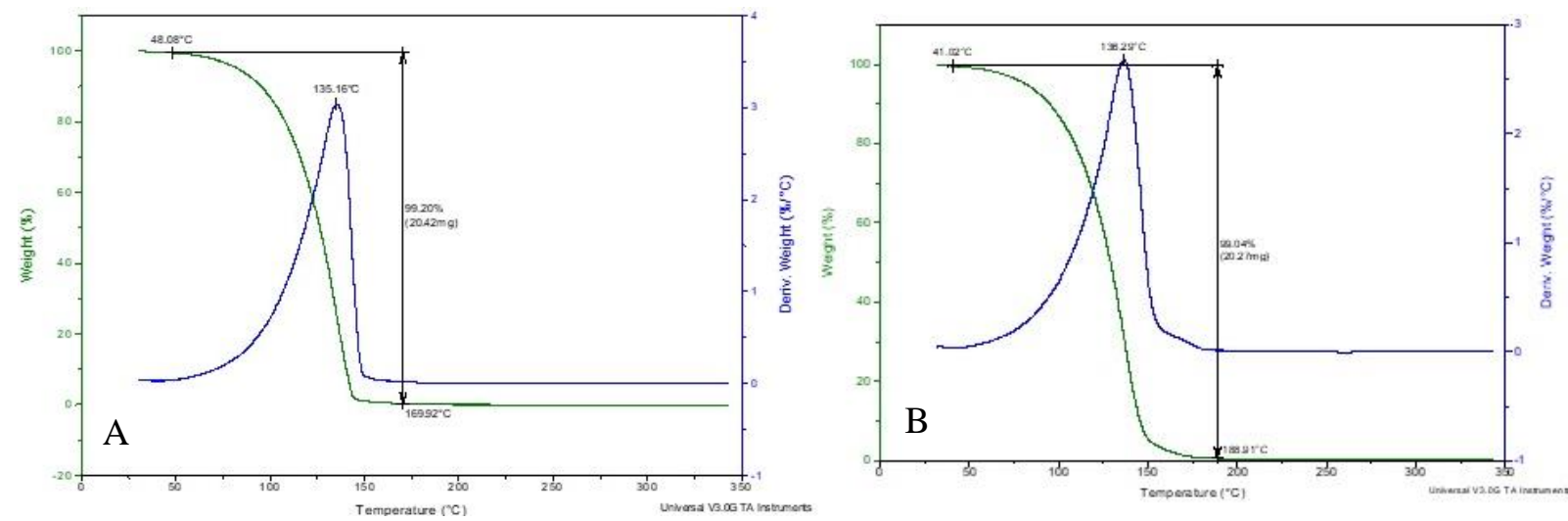

Source: Authors.

Figure 3 is the result of the TG-DTG analysis, in air atmosphere, for $20.58 \mathrm{mg}$ of the standard (Figure $3 \mathrm{~A}$ ) and for $20.46 \mathrm{mg}$ of essential oil of Aniba rosaeodora (Figure 3B). The TG-DTG curve of the Fig. 3A shows a single decomposition step observed between $48.08{ }^{\circ} \mathrm{C}$ and $169.92{ }^{\circ} \mathrm{C}$ with a mass loss of $99.20 \%$ as a consequence of the linalool volatilization process. For the essential oil (Fig. 3B) resulted else in a single endothermic transition between $41.02{ }^{\circ} \mathrm{C}$ and $188.91{ }^{\circ} \mathrm{C}$, with mass loss of $99.04 \%$.

Figure 4. TG-DTG curves, aluminum pan without hole, with a heating rate of $10{ }^{\circ} \mathrm{C} \mathrm{min}-1$, in notrogenio atmosphere for: A) linalool; and B) essential oil of Aniba rosaeodora Ducke.
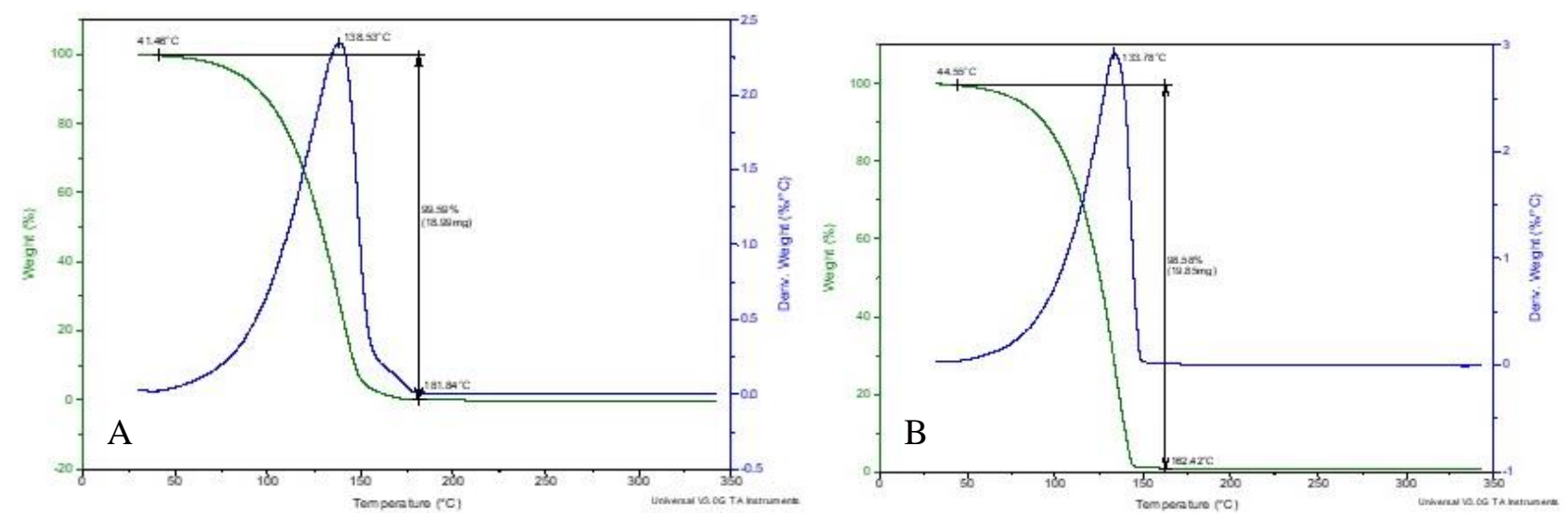

Source: Authors.

The TG-DTG curves shown on Figure 4 were obtained for $20.58 \mathrm{mg}$ of the linalool standard (Figure 4A) and for $19.07 \mathrm{mg}$ of the essential oil (Figure 4A), both in nitrogen atmosphere. It is possible to observe that the linalool volatilization is verified between $44.55{ }^{\circ} \mathrm{C}$ and $162.42{ }^{\circ} \mathrm{C}$ with a mass loss of $98.58 \%$ and the oil volatilization occurs between $41.46{ }^{\circ} \mathrm{C}$ and $181.84{ }^{\circ} \mathrm{C}$, with a mass loss of $99.5 \%$.

The thermogravimetric curves (TG) of the essential oil of the plant species Aniba rosaeodora Ducke and the linalool standad, in different atmospheres, being: Linpar = linalool pattern in air atmosphere; Linpn2 = linalool standard in $\mathrm{N}_{2}$ atmosphere; Olpar = essential oil in air atmosphere; and Olpn2 = essential oil in $\mathrm{N}_{2}$ atmosphere. 
Figure 5. Thermogravimetric curves (TG) of the essential oil of the plant species Aniba rosaeodora Ducke and the linalool standard.

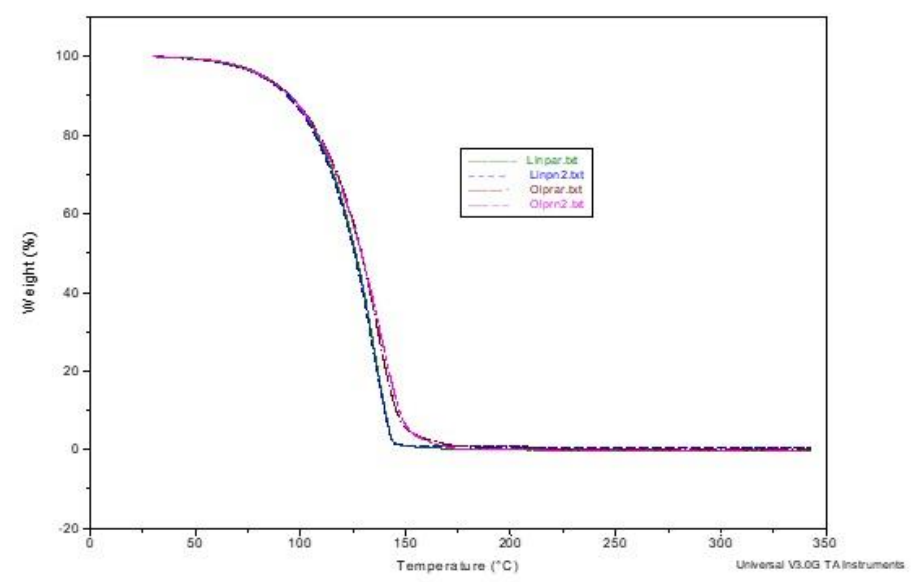

Source: Authors.

\section{Discussion}

Comparing the values for the essential oil of the branches of the Aniba rosaeodora species with those in the literature, it is observed that there is a strong similarity. The substances identified from the chromatogram of the essential oil of Aniba rosaeodora Ducke showed that the major component is linalool, with $89.34 \%$, which is also in agreement with the literature.

The DSC curves for the determination of standard linalool boiling temperatures in air and nitrogen show little variation in the peak temperatures and vaporization enthalpies of linalool. Lower values in an oxidizing atmosphere occur through the reaction of alcohol, forming less polar substances. The difference in peak temperatures and vaporization enthalpies verified in the DSC curves of the air atmosphere in essential oil samples and nitrogen gas is due to the presence of minor components in the oil, whereas the fact to this variation be small is justified by the high content of linalool in the essential oil.

The DSC curves obtained from the linalool standard demonstrated the decomposition of linalool and confirmed the absence of water of hydration. The DSC curves obtained with the essential oil, on the other hand, show an endothermic transition around $100^{\circ} \mathrm{C}$, which may show that the essential oil has water of hydration.

The TG-DTG curves in air (Fig. 3 and Fig. 4) showed a single decomposition step for both standard and essential oil, resulting from the volatilization process of the linalool or the oil. This analysis also showed that they both lost more than 99\% of their mass. The oil starts to lose mass at a temperature lower than the standard temperature and ends up at a slightly higher temperature, which can be explained by the presence of minor components in the oil, as some are more volatile than linalool and others are less.

The difference between the temperature values of the essential oil and the standard is explained by the fact that linalool is the major component in the oil, with $89.34 \%$. The temperature value attributed to the boiling temperature of linalool is similar to that found in the literature (Merk, 1996; Cavalheiros, Chaar, Breviglieri \& Chierice, 2004).

The differences between the boiling points and enthalpies of the measured linalool and essential oil standard are justified by the presence of the minor components, their concentrations in the essential oil and their interactions. It should be considered that the oil has other substances of different polarities, molecular masses and intermolecular forces, which contribute to these differences. 


\section{Conclusion}

The extraction yield of essential oil from Aniba rosaeodora Ducke obtained was 1.87\% (m/m), being major componente the linalool $(89.34 \%)$, followed by $\alpha$-terpineol $(3.06 \%)$.

The thermal analysis of essential oil, using TG-DTG e DSC, opened a new path for essential oil analysis. The results obtained were unprecedented for the essential oil of Aniba rosaeodora Ducke, even allowing to suggest the quantitative determination of linalool by DSC.

As this is a new and efficient technique for determining the boiling temperatures of essential oils, further studies should be carried out in order to broaden its spectrum of scientific investigation of essential oils, as well as envisioning that the technique can be used in certification and quantification of these oils, considering that many of them with high economic value are frequently adulterated.

\section{Acknowledgments}

The authors thank Fapema (Research Support Foundation of Maranhão) for the financial support to the research.

\section{References}

Adams, R. P. (2001) Identification of essential oil components by gas chromatography/mass spectroscopy. 3rd ed., USA; Allured Publishing Corporation. 800 p.

Aslan, D. I, Özoğul, B., Ceylan, S., \& Geyikçi, F. (2018) Thermokinetic analysis and product characterization of Medium Density Fiberboard pyrolysis. Bioresource Technology, 25(8): 105-110. Doi: 10.1016/j.biortech.2018.02.126

Barata, L. E. S. (2012) A economia verde. Amazônia Ciência \& Cultura, 64(3): 31-35. Doi: http://dx.doi.org/10.21800/S0009-67252012000300011

Bernal, C., Couto, A. B., Breviglieri, S. T., \& Cavalheiro E. T. G. (2002) Influence of some experimental parameters on the results of differential scanning calorimetry - DSC. Química Nova, 25(5): 849-855. https://doi.org/10.1590/S0100-40422002000500023

Bizzo, H. R., Hovell, A. M. C., \& Rezende, C. M. (2009) Óleos essenciais no Brasil: aspectos gerais, desenvolvimento e perspectivas. Quím. Nova, 32(3): 588-594. Doi: https://doi.org/10.1590/S0100-40422009000300005

Cavalheiro, É. T. G., Chaar, J. S., Mouchrek Filho, V. E., Breviglieri, S. T., \& Chierice, G. O. (2004) Boiling Temperature and enthalpy changes of essential oil using capillary glass sample holder. Journal of Thermal Analysis, 75(2): 437-443. Doi:10.1023/b:jtan.0000027130.37755.64

Chaar, J da S. (2000) Estudos analíticos e modificação química por acetilação do linalol contido no óleo essencial da espécie Aniba duckei kostermans. Tese de Doutorado. Instituto de Química de São Carlos, USP.

Correa, D. B; Gottilieb, O. R. Duckein, N. A. (1975) Alkaloid from Aniba duckei. Phytochemistry, 14 (1): 271-272. Doi: https://doi.org/10.1016/00319422(75)85053-9

Cremasco, M. A., \& Nazareno, B. P. (2011) Thermogravimetric analysis of long pepper (Piper hispidinervium C.DC.) essential oil. Acta Amazonica. 41(2): 275 - 278. Doi: https://doi.org/10.1590/S0044-59672011000200012

Dantas, M. B. (2006) Obtenção, Caracterização e Estudo Termoanalítico de Biodiesel de Milho (Zea mays L.). João Pessoa, UFPB. Master. 114 p.

Gonçalves, M. L. A., Teixeira, A. M. R, Teixeira, M. A. G. (2003) Applicability of Thermogravimetric Techniques to Pyrolysis Studies of National Oil Waste. In: Annals of the 2nd Brazilian Congress on Oil and Gas R\&D. Rio de Janeiro, CD.

Hasani. S., Ojagh, S. M., \& Ghorbani, M. (2018) Nanoencapsulation of lemon essential oil in Chitosan-Hicap system. Part 1: Study on its physical and structural characteristics. International Journal of Biological Macromolecules, 115(8), 143-151. Doi: 10.1016/j.ijbiomac.2018.04.038

Hazra, A., Alexander, K., Dollimore, D., \& Riga A. (2004) Characterization of some essential oils and their key components. Journal of Thermal Analysis and Calorimetry, 75(1): 317-330. Doi: https://doi.org/10.1023/B:JTAN.0000017352.86803.6d

Hazra, A., Dollimore, D., \& Alexander, K. (2002) Thermal analysis of the evaporation of compounds used in aromatherapy using thermogravimetry. Thermochimica Acta. 392(1): 221-229. Doi: 10.1016/S0040-6031(02)00104-1

Ionashiro, M. Giolito, I. (2004) Fundamentos da Termogravimetria, Análise Térmica Diferencial e Calorimetria Exploratória Diferencial. Brazil: Giz Editorial: p.82.

Joly, C. A., Haddad, C. F. B., Verdade, L. M., Oliveira, M. C., Bolzani, V. D. S., \& Berlinck, R. G. S. (2011) Diagnóstico da pesquisa em biodiversidade no Brasil. Revista USP, 89(1): 114-133. Doi: https://doi.org/10.11606/issn.2316-9036.v0i89p114-133 
Kreutz, T., Carneiro, S. B., Soares, K. D., Limberger, R. P., Apel, M. A., Veiga Junior, V. F., \& Koester, L. S. (2021) Aniba canelilla (Kunth) Mez essential oil-loaded nanoemulsion: Improved stability of the main constituents and in vitro antichemotactic activity. Industrial Crops and Products, 171(1): 1-8. Doi: https://doi.org/10.1016/j.indcrop.2021.113949

Mackenzie, R. C. (1993) Origin and Development of the International Confederation for Thermal Analysis (ICTA). Journal of Thermal Analysis and Calorimetry, 40(1): 5-28. Doi: https://doi.org/10.1007/BF02546552

Maia, J. G. S., \& Andrade, E. H. A. (2009) Database of the Amazon aromatic plants and their essential oils. Química Nova, 32 (3): 595-622. Doi: https://doi.org/10.1590/S0100-40422009000300006

Maia, J. G. S. (2000) Plantas aromáticas na amazônia e seus óleos essenciais. Brazil; Museu Paraense Emílio Goedi,180p.

Mallick, D., Poddar, M. K., Mahanta, P., Moholkar, V. S. (2018) Discernment of Synergism in Pyrolysis of Biomass Blends Using Thermogravimetric Analysis. Bioresource Technology, 2018; 261(1): 294-305. Doi: https://doi.org/10.1016/j.biortech.2018.04.011

Merk. (1996) The Merk Index, S. Budavari, 12th ed., Brazil; Merk and Co.

Monteiro, O. S., Souza, A. G., Soledade, L. E. B., Queiroz, N., Souza, A. L., Filho Mouchrek, V. E, \& Vasconcelos, A. F. F. (2011) Chemical evaluation and thermal analysis of the essential oil from the fruits of the vegetable species Pimenta dioica Lindl. Journal of Thermal Analysis and Calorimetry, 106(1): 595600. DOI: 10.1007/s10973-011-1438-4

Namara, K. M., Howell, J., Huang, Y., \& Robbat Jr, A. J. (2007) Analysis of gin essential oil mixtures by multidimensional and one-dimensional gas chromatography/mass spectrometry with spectral deconvolution. Journal of Chromatography A, 1164(1-2): 281-290. Doi: 10.1016/j.chroma.2007.07.042

Nazir, N., Zahoor, M., \& Uddin, F. (2021) Chemical composition, in vitro antioxidant, anticholinesterase, and antidiabetic potential of essential oil of Elaeagnus umbellata Thunb. BMC Complementary Medicine and Therapies, 21(1): 73. Doi: https://doi.org/10.1186/s12906-021-03228-y.

Oussalah, M., Caillet, S., Saucier, L., \& Lacroix, M. (2007) Inhibitory effects of selected plant essential oils on the growth of four pathogenic bacteria: E. coli O157:H7, Salmonella Typhimurium, Staphylococcus aureus and Listeria monocytogenes. Food Control, 18(5): 414-420. Doi: https://doi.org/10.1016/j.foodcont.2005.11.009.

Sampaio, P. T. B.; Barbosa, A; \& Vieira, G. (2005) Canopy sprouting biomass of rosewood (Aniba rosaeodora Ducke) in an Amazonian terra firme forest. Acta Amazonica, 35(4): 491-494. Doi: 10.1590/S0044-59672005000400014

Santos, J.C.O., Souza, A.G., Trindade, M.F.S., Santos, I.M.G., \& Conceição, M.M. (2004) Thermal Analysis of Rice and by-Products. Journal of Thermal Analysis and Calorimetry, 75(2): 393-399. Doi: 10.1023/B:JTAN.0000027125.77040.43

Siani, A.C.; Sampaio, A.L.F.; Souza, M.C.; Henriques, M.G.M.O.; \& Ramos, M.F.S. (2000) Óleos Essenciais: Potencial antiinflamatório. Biotecnologia, Ciência \& Desenvolvimento, 16(1): 38-43. Doi:

Silverstein, R. M, Webster, F. X. Spectrometric Identification of Organic Compounds, 7th. ed., Brazil; LTC: 2007: 480p.

Siqueira, G. L. de A. de., Lazzarotto, M., Fernandes, M., Silveira, A. C. da., Lazzarotto, S.R. da S., Carvalho Filho, M.A. da S., Lacerda, L.G., Queiroz, D.L. de., \& Miguel, O.G. (2016) Thermoanalytical evaluation of essential oils of the leaves from Eucalyptus spp susceptible and resistant to Glycaspis brimblecombei. Brazilian Journal of Thermal Analysis, 5(1): 1-6. DOI:10.18362/bjta.v5.i1.1

SUDAM. (1971) O extrativismo do pau-Rosa (Aniba duckei Kosterm. - Aniba roseadora Duckei). Aspectos sócio-econômicos, a silvicultura da espécie. SUDAM documenta, Belém, 3(1): 5-55.

Teles, R. de M., Mouchrek Filho, V.E., Souza, A.G. de. (2017) Chemical Characterization and Larvicidal Activity of Essential Oil from Aniba duckei Kostermans against Aedes aegypti. International Journal of Science and Research, 3(6):1495-1499. Doi: 10.21276/ijlssr.2017.3.6.11

Teles, R. de M., Mouchrek Filho, V.E.M., Mouchrek, A. N. Chemical Composition and Antibacterial Activity of Essential Oil of Aniba duckei Kosterman. International Journal of Science and Research, 2015; 3(6):1495-1499. Doi: 10.21276/ijlssr.2018.4.2.7

Tuğçe, M., Halil, T., \& Odabaş, İ. (2021) Single-step recovery of pectin and essential oil from lemon waste by ohmic heating assisted extraction/hydrodistillation: A multi-response optimization study. Innovative Food Science \& Emerging Technologies, 74(102850): 1-10. Doi: https://doi.org/10.1016/j.ifset.2021.102850

Vivan, A. G..; Barboza, F. S.; Luz, M. L. G. S.; Luz, C. A. S.; Ramirez, O. P.; Gomes, M. C.; Soares, F. C. (2011) Technical and economic study of a mobile system for extraction of eucalyptus essential oil, Cerne; 17(1): 23-31. Doi: https://doi.org/10.1590/S0104-77602011000100004 